\title{
NEUROPHARMACOLOGICAL SCREENING, ANTI-STRESS ACTIVITY, AND TOXICITY STUDIES OF STANDARDIZED EXTRACT OF THE SEEDS OF CELASTRUS PANICULATUS WILLD
}

\author{
SWATI SINGH ${ }^{1 *}$, ASHUTOSH UPADHYAY ${ }^{1}$, ANUP KUMAR SIRBAIYA ${ }^{2}$ \\ ${ }^{1}$ Department of Pharmaceutical Sciences NIMS University, Jaipur, Rajasthan, India. ${ }^{2}$ Department of Pharmaceutical Chemistry, Faculty of \\ Pharmacy, Integral University, Lucknow, Uttar Pradesh, India. Email: swati.29.singh@gmail.com
}

Received: 27 June 2021, Revised and Accepted: 20 September 2021

\section{ABSTRACT}

Objective: Celastrus paniculatus Willd, family Celastraceae is an important medicinal plant distributed all over India. Due to the presence of antioxidative polyphenols in $C$. paniculatus Willd have received much attention for health-promoting properties by scavenging the free radicals, the purpose of this study is to understand neuropharmacological, anti-stress activity, and toxicity studies of standardized seeds extract of "C. paniculatus Willd.

Methods: The sun dried $C$. paniculatus Willd seeds were collected and extracted with ethanol by maceration. Then, the ethanolic extract was subjected to phytochemical screening. The acute toxicity of the ethanolic extract of $C$. paniculatus was observed as per the Organization for Economic Co-operation and Development guideline no. 423. Neuropharmacological and anti-stress effects were analyzed and evaluated by using physical stress models such as Swimming endurance test, Anoxic tolerance test, Tail suspension test (TST), and Elevated plus maze test. For this study, Swiss albino mice (20-30 g) were divided into five groups of six animals each. Distilled water administered as vehicle in control group and standard group received Withania somnifera $(100 \mathrm{mg} / \mathrm{kg})$ while $C$. paniculatus Willd ethanolic extract $(100,200$, and $400 \mathrm{mg} / \mathrm{kg})$ was given orally for 7 days.

Results and Discussion: Change in immobility time in swim endurance, first clonic convulsion produced in anoxic tolerance test, immobility time in TST and open arms entry in elevated plus maze test was recorded as parameters. The ethanolic extracts of $C$. paniculatus Willd significantly reduces the immobility timing along with increases the swimming endurance time, and clonic convulsion timing in anoxic tolerance test in comparison of control group. In tail suspension significant decrease in immobility time and increased open arm entry in elevated plus maze were observed as compare to control group.

Conclusion: C. paniculatus Willd has potential as a medicinal plant and it showed protective effect for the stress prevention as the alkaloids are present as main constituents.

Keywords: Anoxic tolerance test, Anti-stress, Celastrus paniculatus, Neuropharmacological, Swim endurance test, Tail suspension test, Toxicity studies.

(C) 2021 The Authors. Published by Innovare Academic Sciences Pvt Ltd. This is an open access article under the CC BY license (http://creativecommons.org/ licenses/by/4.0/) DOI: http://dx.doi.org/10.22159/ajpcr.2021v14i11.42557. Journal homepage: https://innovareacademics.in/journals/index.php/ajpcr

\section{INTRODUCTION}

As stated by the World Health Organization WHO, mental well-being is a part of health [1]. Stress is a phenomenon experienced by individuals that have become an integral part of modern human life. It is a biological response that can cause anxiety in an organism [2]. Hence, when stress becomes extreme, it is harmful to the body and, hence, needs to be treated [3]. Stress has been supposed to be involved in the etiopathogenesis of a different disease states, that is hypertension, peptic ulcer, diabetes, immunosuppression, reproductive dysfunctions, and behavioral turbulence such as anxiety because having involvement of the central nervous system, endocrine system, and metabolic system [4]. Stress enhances the action of endocrine system to release a high number of glucocorticoids and catecholamines. The continuous state of stress increases free radicals, which leads to cause abnormal physiological state development of psychological and cognitive dysfunction. These ROS can cause tissue injury by reacting with proteins, lipids, DNA resulting in various pathological situations [5]. A lot of drugs possess anti-stress activities, originate non-specific resistance against stressed conditions. Benzodiazepines, amphetamine, caffeine, and some other a like drug regularly prescribed in condition of stress. The incidence of toxicity and dependence has limited the therapeutic use of these drugs [6].

Recently, the use of natural extract for treating neurological, psychiatric, and neurotoxicological disorders has been increased tremendously due to their no or fewer side effects. Scopolamine and also contributed to gain knowledge about new therapeutically active compounds obtained from the herbal extract. These compounds can be used directly as footprints for the developing new medicines or as pharmacological tools to discover new active compounds [7].

Various plants are being used in complementary and alternative medicines for the management of stress. The vigorous use of safer as well as cheaper herbal medicines have been reported as anti-stress agent because they can reduce stress without affecting the physiology of human body [8].

In the Indian context, some plants that have been traditionally used like Celastrus paniculatus Willd which is commonly known as "Black seed oil plant" and it is called in Ayurveda as "Tree of life" belongs to family Celastraceae (Fig.1) $[9,10]$. In Ayurveda, the ancient Indian traditional system of medicine has used the plant seed for the prevention of various diseases [11]. It is a large woody, climbing shrub that grows on the height up to 10-18 m tall and very common all over the hilly area of India [12]. The bark is abortifacient, depurative, and a brain tonic. C. paniculatus Willd roots are useful against scorpion bites [13]. The use of leaves to regulate menstrual cycle in women and leaf sap is used to cure opium poisoning [14]. Alkaloids, named as, celastrine, paniculatine celapanin, celapanigin, and celapagin are isolated as active constituents. Seeds contain brownish-yellow oil, bitter resinous component, tannin, and ash. In this plant sesquiterpene alkaloids are 
obtain from a new sesquiterpene tetra-ol (celapanol). C. paniculatus Willd also contain some minerals such as sodium, magnesium, aluminum, potassium, calcium, vanadium, chromium, manganese, iron, cobalt, nickel, copper, zinc, and molybdenum. The extract of areal part of plant in hydro-alcohol was constituted $3.52 \%$ of tannins (Fig.2) [15].

From the literature review, regarding the traditional uses and phytochemical properties of $C$. paniculatus Willd extract studied for a different activity such as anti-nociceptive, nootropic activity, neuromodulating effect, tranquilizing effect, cognitive enhancing properties learning, and memory effect, sedation and anti-convulsion activity, antioxidant, analgesic and anti-inflammatory, hypolipidemic, anti-arthritic activity, anti-fertility, wound healing activity, anti-malarial activity, anti-bacterial activity, anti-fungal activity, immune modulatory activity, anti-depressant activity, and iron chelating activity [16].

Thus, the therapeutic measure concerning the anti-stress activity of C. paniculatus Willd was taken into consideration in the present work. In this study, we investigate the Neuropharmacological screening and anti-stress activity of the ethanolic extract of $C$. paniculatus Willd. (EECP) in the behavioral animal models.

\section{METHODS}

\section{Collection and authentication of plant materials}

For this study, the seeds of $C$. paniculatus Willd were procured from local market of Lucknow, Uttar Pradesh in the month of September 2019 and authenticated from Integral University, Lucknow. Voucher specimens were preserved for future reference.

\section{Preparation of extract}

Coarsely powdered seeds were extracted with ethanol-water by maceration in a closed vessel for $72 \mathrm{~h}$. At the interval of $24 \mathrm{~h}$, the

Table 1: Grouping of animals

\begin{tabular}{lllll}
\hline $\begin{array}{l}\text { S. } \\
\text { No. }\end{array}$ & Group & Treatment & Dose/Route & $\begin{array}{l}\text { Number } \\
\text { of animals }\end{array}$ \\
\hline 1. & Control & CMC & $5 \mathrm{ml} / \mathrm{kg}$, p.o. & 6 \\
2. & Standard & Ashwagandha & $100 \mathrm{mg} / \mathrm{kg}$, p.o. & 6 \\
3. & Test 1 & $\begin{array}{l}\text { Celastrus paniculatus } \\
\text { (EECP 1) }\end{array}$ & $100 \mathrm{mg} / \mathrm{kg}$, p.o. & 6 \\
4. & Test 2 & $\begin{array}{l}\text { Celastrus paniculatus } \\
\text { (EECP 2) }\end{array}$ & $200 \mathrm{mg} / \mathrm{kg}$, p.o. & 6 \\
5. & Test 3 & $\begin{array}{l}\text { Celastrus paniculatus } \\
\text { (EECP 2) }\end{array}$ & $400 \mathrm{mg} / \mathrm{kg}$, p.o. & 6 \\
\hline
\end{tabular}

Table 2: Effect of EECP on immobility time in swimming endurance test

\begin{tabular}{lll}
\hline S. No. & Treatment & $\begin{array}{l}\text { Duration of immobility } \\
\text { in sec }\end{array}$ \\
\hline 1. & Control & $482.33 \pm 1.82$ \\
2. & Ashwagandha, $100 \mathrm{mg} / \mathrm{kg}$, p.o. & $241.33 \pm 2.29$ \\
3. & CPEE $(100 \mathrm{mg} / \mathrm{kg}$, p.o.) & $314.83 \pm 291$ \\
4. & CPEE $(200 \mathrm{mg} / \mathrm{kg}$, p.o.) & $291 \pm 1.97$ \\
5. & CPEE $(400 \mathrm{mg} / \mathrm{kg}$, p.o.) & $247 \pm 1.8$ \\
\hline
\end{tabular}

Table 3: Effect of EECP on time of convulsion anoxic tolerance test

\begin{tabular}{lll}
\hline S. No. & Treatment & Time of convulsion in min \\
\hline 1. & Control & $41.40 \pm 0.79$ \\
2. & Ashwagandha, $100 \mathrm{mg} / \mathrm{kg}$, p.o. & $81.67 \pm 1.54$ \\
3. & CPEE $(100 \mathrm{mg} / \mathrm{kg}$, p.o. $)$ & $56.04 \pm 1.07$ \\
4. & CPEE $(200 \mathrm{mg} / \mathrm{kg}$, p.o. & $66.17 \pm 1.49$ \\
5. & CPEE $(400 \mathrm{mg} / \mathrm{kg}$, p.o. $)$ & $73.21 \pm 1.39$ \\
\hline
\end{tabular}

used ethanol was changed with fresh amount ethanol. Occasional shaking was done during the extraction period. The ethanolic extract of seeds was filtered, pooled and vacuum concentrated using a rotary evaporator. The dark brown colored sticky residue was collected after the complete removal of the solvent. EECP thus obtained, was used for biological activity [17].

\section{Phytochemical evaluation}

EECP subjected to qualitative identification of phytochemical constituents by using a well-described method in Pharmacognosy Practical book by Dr. Kokate [18].

Drugs and chemicals

Ashwagandha, (Divya Pharmacy, Uttarakhand), CMC, Chemical-Ethanol (SD fine Chem Ltd).

\section{Animals}

Swiss albino mice 20-30 g of either sex were used in the experimentation. After random grouping, animals were caged in a well-ventilated polypropylene cage. Animals were accommodated for a period of 7 days before dosing under standard husbandry conditions as follows.

- Room temperature: $20 \pm 3^{\circ} \mathrm{C}$

- Relative humidity: $45-55 \%$

- $12 \mathrm{~h}$ light/dark cycle

Rodent pellet diet and water ad libitum gave to animal's hygienic conditions. The study protocol was approved by the Institutional Animal Ethics Committee which was formed per norms of the Committee for the

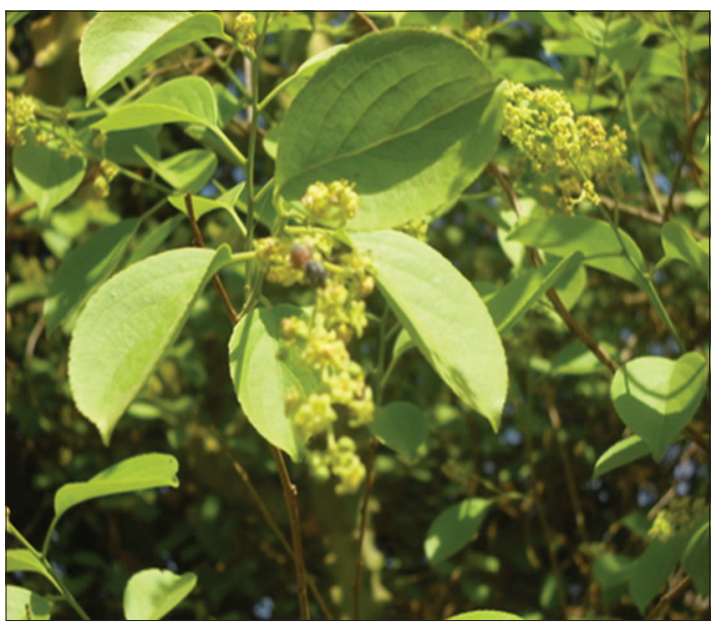

Fig. 1: Plant of Celastrus paniculatus Willd

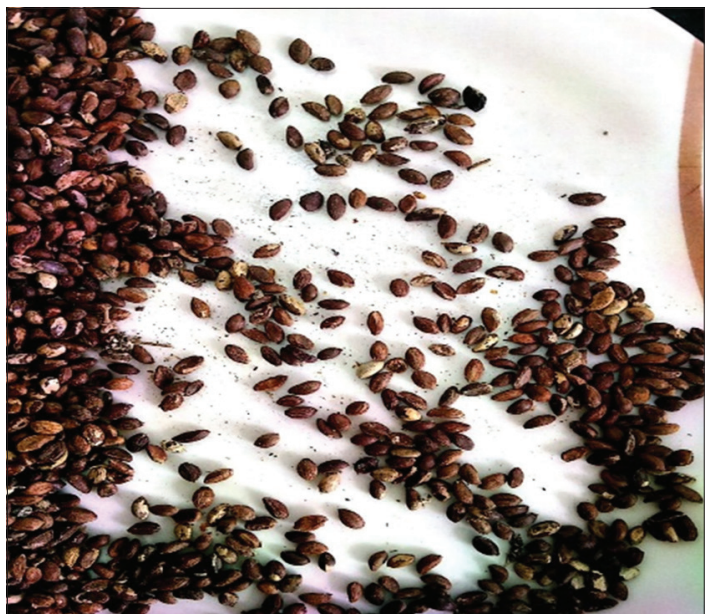

Fig. 2: Seed of Celastrus paniculatus Willd 


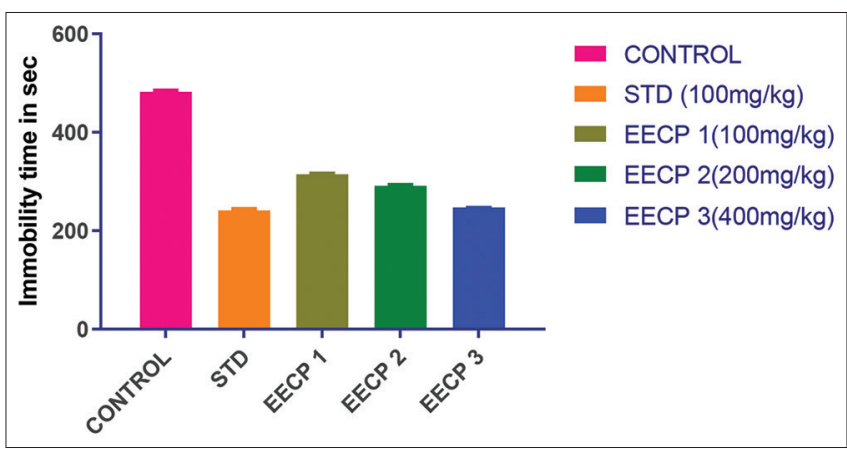

Fig. 3: Effect of EECP on immobility time of swimming endurance test in mice

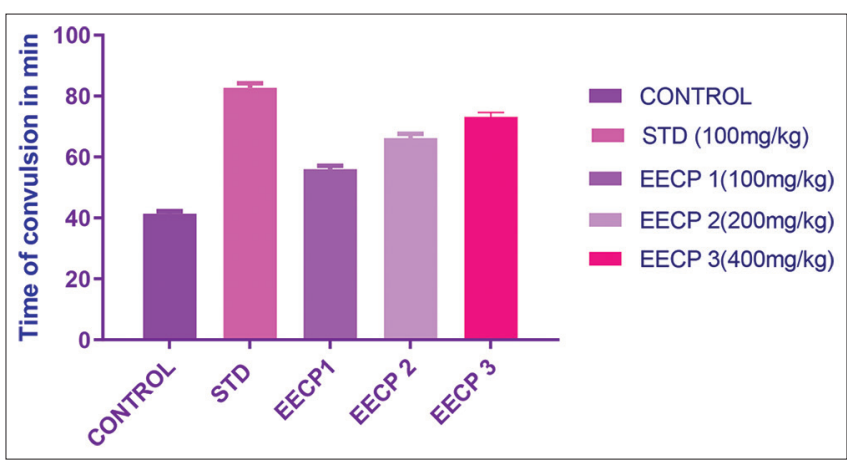

Fig. 4: Effect of EECP on time of convulsion anoxic tolerance test in mice

Purpose of Control and Supervision of Experiments on Animals (CPCSEA) Reg No-1896/PO/Re/S/16/ CPCSEA and complies with the National Institutes of Health guidelines on the handling of experimental animals.

\section{Acute toxicity study}

The animals fasted overnight before the experiment. The acute toxicity of EECP was observed as per the Organization for Economic Co-operation and Development guideline no. 423. It was concluded that EECP not lethal even at a dose of $2000 \mathrm{mg} / \mathrm{kg}$ body weight. Hence, $100 \mathrm{mg} / \mathrm{kg}, 200 \mathrm{mg} / \mathrm{kg}$, and $400 \mathrm{mg} / \mathrm{kg}$ doses were selected for the present study.

\section{Assessment of behavioral parameter \\ Swimming endurance test}

Swiss albino mice were randomized in five groups and each group contain six animals (Table 1). The treatment (EECP) was given to mice orally, for 7 days. To perform this activity using a propylene vessel or water tank $(45 \times 40 \times 30)$ with a water level of $20 \mathrm{~cm}$. On the 7 day, $1 \mathrm{~h}$. after administration of the drug each mice was allowed to swim individually. The immobility duration was measured for a period of $30 \mathrm{~min}$. The mice were assumed to be static whenever they remained floating passively without struggling in water with their head above the water. After each swim session, the mice were taken out from the water, dried with a towel, and placed in closed warm cabin for $10 \mathrm{~min}$ and then to their respective cage. The washing of container was done after testing each animal [7].

\section{Anoxic tolerance test}

The treatment (EECP) was given to mice orally, for 7 days. $500 \mathrm{ml}$ capacity conical flasks were used for performing this test. Before performing the experiment, these flasks were covered by cotton plugs. On the $7^{\text {th }}$ day, $1 \mathrm{~h}$ after administration of the drug each mice was gone to anoxic stress by putting them in a confined airtight $500 \mathrm{ml}$ conical flask. The difference between animal entry time and time of appearance of first clonic convulsion was considered as end point. The mice were taken out at once from the flask for healing and resuscitated if needed. The washing of flask was done after testing each animal [19].

\section{Elevated plus maze test}

The treatment (EECP) was given to mice orally, for 7 days. On the $7^{\text {th }}$ day, after $60 \mathrm{~min}$ of dosing, the mice were placed individually in the maze's center with its head facing the open arm, and following behavioral parametric data were recorded for $5 \mathrm{~min}$;

- Number of entries into the open arm

- Number of entries into the closed arm

- Time spent in the open arm

- Time spent in the closed arm.

Performance of animal to opened/enclosed arm, average time spent in open arm and number of entries in open arm in each group was compared. Cleaning of arena was done thoroughly after testing [6].

\section{Tail suspension test (TST)}

The treatment (EECP) was given to mice orally, for 7 days. With micropore, adhesive tape (approximately $1 \mathrm{~cm}$ ) mice were suspended individually by end of the tail in the suspension box putting the head $50 \mathrm{~cm}$ from the bottom for $40 \mathrm{~min}$ post restraint stress procedure. Suspension time of mice was $6 \mathrm{~min}$. After $4 \mathrm{~min}$ interval of the test immobility time was recorded. When mice will be completely motionless then only, they were considered immobile [20].

\section{Statistical analysis}

Experimental results were expressed as means \pm SEM. The data were analyzed by an analysis of variance, one-way ANOVA followed by Tukey test.

\section{RESULTS}

\section{Qualitative phytochemical screening}

The phytochemical analysis of the EECP shown the presence of alkaloids, steroids, terpenoids, amino acid and tannins.

\section{Effect of EECP in swimming endurance test}

All three doses of EECP showed dose-dependent, decreased immobility time in comparison to the normal control group and increased swimming performance time. Similarly, Ashwagandha (100 mg/kg, p.o.) also showed a statistically significant increase in the swimming time in comparison to the control (Table.2 and Fig. 3).

Results expressed as Mean \pm SEM significant at ${ }^{* * *} \mathrm{p}<0.001$ versus control group by one-way ANOVA followed by Tukey test.

\section{Effect of EECP in anoxic tolerance test}

In this study, all the doses of EECP significantly enhanced anoxia stress tolerance time, evidenced by delaying clonic convulsive signs, in comparison to control animals. Similarly, Ashwagandha treatment also showed a prominent delay in first clonic convulsions (Table 3 and Fig. 4).

Results expressed as Mean \pm SEM significant at ${ }^{*} \mathrm{p}<0.05$ versus control group, ${ }^{* * *} \mathrm{p}<0.001$ versus control group by one-way ANOVA followed by Tukey test.

\section{Effect of EECP in TST}

All the doses of EECP showed a dose-dependent decrease in immobility time when it was compared against normal control as well as against Ashwagandha, used as a standard. The results of TST are shown in Table 4 and Fig. 5.

Results expressed as Mean \pm SEM significant at ${ }^{* * *} p<0.001$ versus control group by one-way ANOVA followed by Tukey test.

\section{Effect of EECP in elevated plus maze test}

Vehicle-treated mice had made a smaller number of open and closed arms entries and spent less time in open and more in closed arms, respectively, as compared to other groups, which indicates anxiogenic behavior of mice. Treatment of drugs during the stress period significantly justified the anxiolytic behavior as evidenced by increasing 
Table 4: Effect of EECP on immobility time of tail suspension test

\begin{tabular}{lll}
\hline S. No. & Treatment & Immobility \\
\hline 1. & Normal control & $127.50 \pm 1.56$ \\
3. & Ashwagandha $100 \mathrm{mg} / \mathrm{kg}, \mathrm{p} .0$. & $65.17 \pm 1.49$ \\
4. & CPEE $(100 \mathrm{mg} / \mathrm{kg}, \mathrm{p} . \mathrm{o})$. & $89.33 \pm 1.76$ \\
5. & CPEE $(200 \mathrm{mg} / \mathrm{kg}, \mathrm{p} .0)$. & $85.17 \pm 1.94$ \\
6. & CPEE $(400 \mathrm{mg} / \mathrm{kg}, \mathrm{p} . \mathrm{o})$ & $72.83 \pm 1.58$ \\
\hline
\end{tabular}

Table 5: Effect of EECP on number of entries in open arm in elevated plus maze test

\begin{tabular}{lll}
\hline S. No. & Treatment & $\begin{array}{l}\text { Number of entries (5 min) } \\
\text { in Open Arm }\end{array}$ \\
\hline 1. & Normal control & $71.50 \pm 0.98$ \\
3. & Ashwagandha $100 \mathrm{mg} / \mathrm{kg}$, p.o. & $256.00 \pm 1.39$ \\
4. & CPEE $(100 \mathrm{mg} / \mathrm{kg}$, p.o.) & $122.83 \pm 1.69$ \\
5. & CPEE $(200 \mathrm{mg} / \mathrm{kg}$, p.o.) & $135.83 \pm 1.39$ \\
6. & CPEE $(400 \mathrm{mg} / \mathrm{kg}$, p.o.) & $186.17 \pm 1.28$ \\
\hline
\end{tabular}

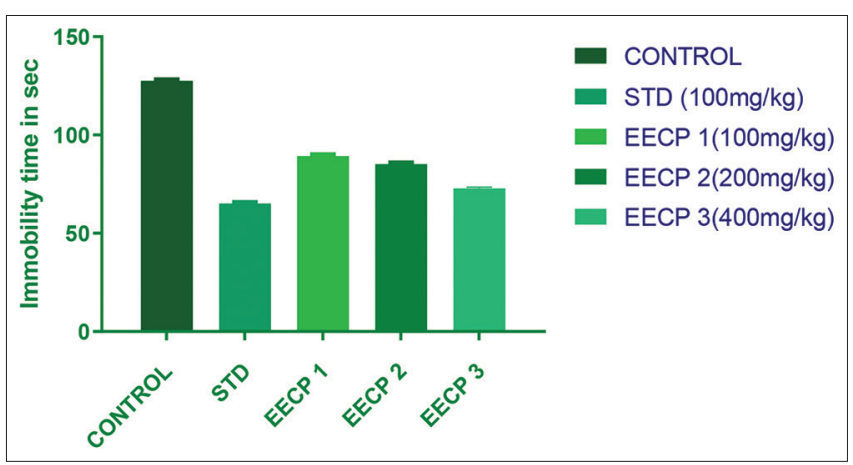

Fig. 5: Effect of EECP on immobility time of tail suspension test in mice

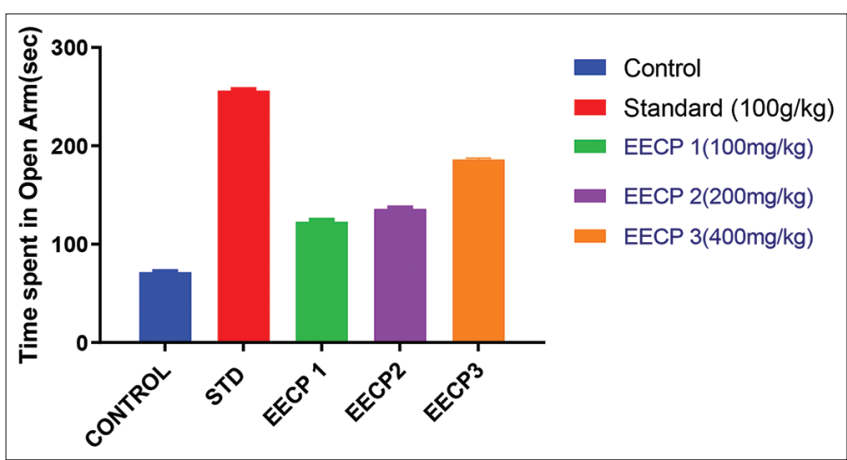

Fig. 6: Effect of EECP on number of entries in open arm in elevated plus maze test in mice

and decreasing time spent in open arm and closed arm respectively when compared to (-ve control group). Drug-treated groups produced a significant difference in entries in close and open arms in comparison to positive control group (Table 5 and Fig. 6).

Results expressed as Mean \pm SEM significant at ${ }^{*} \mathrm{p}<0.05$ versus control group, ${ }^{* * *} \mathrm{p}<0.001$ versus control group by one-way ANOVA followed by Tukey test

\section{DISCUSSION}

Many human diseases are produced from stress, which is caused by free radicals. Free radicals are responsible for major damage in the body. Modern lifestyles have enhanced the exposure of human beings to stressful conditions resulting in physical, psychological abnormalities. Therefore, it is required to enhance the adaptability of human beings to stressful conditions. Synthetic drugs cannot use at broad spectrum due to their higher cost and side effect associated with them, so the researchers looking for alternative methods like Yoga, Herbal medicines [21]

The treatment mainly focused on the management of stress which is a link to another chronic disease (stress and diabetes). Stress is associated to activate the hypothalamic-pituitary-adrenal axis, which results in release of corticotrophin-releasing hormone (CRH) from the hypothalamic periventricular nucleus. CRH stimulates anterior pituitary to secrete an adrenocorticotropic hormone, which in turn provokes the adrenal cortex to release corticosterone. Corticosterone has lipophilic nature so it easily crosses to brain barrier. The hormone acts at those sites of brain where corticosteroid receptors are expressed such as in limbic areas. In the brain neuropeptides are released extensively while the stress condition is there [22].

In this study, the anti-stress activity of EECP has been evaluated at given doses $(100,200$, and $400 \mathrm{mg} / \mathrm{kg})$ using different acute stress behavioral tests like swimming endurance tests, anoxic tolerance, TST, and elevated plus maze test.

The swimming Endurance Test is a broadly accepted model for evaluating anti-stress activity and it is based on monitoring that animals swim in the water, assumed a specific immobile posture, without of any activity. The appearance of immobility therefore shows a condition of decrease stamina, fatigue, and tiredness with the endpoint being the movement when the animal could not swim further and started drowning. The results of the swimming test demonstrated the significant increase in swimming time in mice, pre-treated for 7 days with test extract with increased physical performance and therefore assuring its anti-stress property [6].

All the physiology of body, including cellular respiration, depends on oxygen supply. All body mechanisms will be disturbed when any vital element lacks. Depletion of any vital elements increases adaptation during stress by any drug that enhances the tolerance can act as an adaptogenic agent. Adaptogens producing beneficial effects in stress are believed to act by increasing non-specific resistance. In this study depletion of oxygen in hermetic vessels leads to convulsions in animals and pretreatment with EECP had increased the stress tolerance indicating their anti-stress activity [23].

C. paniculatus Willd is known for its neuroprotective effect due to its antioxidant potential. In this study this property is considered to be responsible for its protective effect. Prolongation of mean time to convulsion could be as a result of its powerful antioxidant and free radical scavenging activities [24].

TST shows significant sensitivity to monoamine. In this study, EECP shows remarkable reduction in the immobility at the highest dose of $400 \mathrm{mg} / \mathrm{kg}$ which was compared to standard drug. Thus, the anti-stress activity showed probably by inhibiting Monoamine Oxidase-A and Monoamine Oxidase-B [25].

It has been concluded that EECP, exhibits neuroprotective and cognitive-enhancing effects, i due to it can modulate cholinergic system and contrast with oxidative stress [26].

In our studies, EECP significantly increases the time spent in open arms and the number of entries in the open arm while time spent in closed arms decreased significantly indicating that the plant showed anti-stress activity [6].

In this study alkaloid, tannin, and flavonoids of crude extract of the title plant may be responsible for observed anti-stress/adaptogenic and anxiolytic activities. 


\section{CONCLUSION}

This study was investigated the putative behavioral effects of EECP in various acute stress models. Results of the behavioral model revealed that EECP having higher anti-stress activity at the dose of $400 \mathrm{mg} / \mathrm{kg}$ p.o. The anti-stress activity of EECP was probably due to its anti-oxidant property due to the presence of alkaloids. These results are motivating to continue further studies on the other active fractions of these extract to emphasize on other characteristics feature of $C$. paniculatus Willd.

\section{DECLARATION OF CONFLICTING INTEREST}

The authors declare that there is no any conflict of interest as the present work is solely done by the authors.

\section{AUTHORS FUNDING}

There is no any financial support provided from the parent institute and any other funding agency for the conduct of this research and/or preparation of the article.

\section{REFERENCES}

1. Pawar VS, Shivakumar H. A current status of adaptogens: Natural remedy to stress. Asian Pac J Trop Dis 2012;2:480-90.

2. Lailatussifa R, Husni A, Endro A. Nugroho Anti-stress activity of Sargassum polycystum extracts using a cold restraint stress model. Food Sci Biotechnol 2016;25:589-94

3. Tiwari N, Mishra A, Bhatt G, Chaudhary A. Anti-stress activity (in-vivo) of forskolin isolated from Coleus forskohlii. Int J Pharm Phytopharmacol Res 2014;4:201-4

4. Anssari ZM, Fasiuddin M, Salman S, Nazer S, Imran M, Toufeeq M, et al. Pharmacological screening of polyherbal formulation for anti-stress activity on Albino rats. Int J Pharmacol Res 2015;5:125-8.

5. Marasani A, Latha DS, Kumar KE. Phytochemical, Antioxidant, Anti-stress and Cerebro-protective activity of ethyl acetate extract of bark of Entada rheedi. Int J Res Pharm Sci 2019;10:1612-20.

6. Nanjappaiah HM, Patil VP, Muchchandil S, Chandrashekar VM, Shivakumar H. Screening of antistress and anxiolytic activities of Piper longum fruits extract. J Pharm Biosci 2017;5:1-11.

7. Malleswari NM, Goud HD, Nandimandala VK. Anti-stress activity of Tinospora cardifolia in albino rats by oral route. Eur J Biomed Pharm Sci 2018:5:569-73

8. Jahagirdar MQ, Hugar S, Patil VP, Khot A, Nanjappaiah HM. Screening of antistress activity of Ficus benghalensis fruit extract. Res J Pharm Tech 2020;13:191-6.

9. Deodhar KA, Shinde NW. Celastrus paniculatus: Traditional uses and ethnobotanical study. Indian J Adv Plant Res 2015;2:18-21.

10. Younus MD. Ethno botanical study and traditional uses of Celastrus paniculatus. Int J Innov Sci Eng Technol 2015;2:139-43.
11. Atigari VD, Gundamaraju R, Sabbithi S, Chaitanya K, Ramesh C. Evaluation of antiepileptic activity of methanolic extract of Celastrus paniculatus Willd whole plant in rodents. Int J Pharm Phytopharmacol Res 2012;2:20-5

12. Arora N, Rai SP. GC-MS analysis of the essential oil of Celastrus paniculatus Willd. seeds and antioxidant, anti-inflammatory study of its various solvent extracts. Ind Crops Prod 2014;61:345-51.

13. Parimala S, Shashidhar GH, Sridevi C, Jyothi V, Suthakaran R. Anti-inflammatory activity of Celastrus Paniculatus seeds. Int J PharmTech Res 2009;1:1326-9.

14. Debnath M, Biswas M, Nishteswar K. Evaluation of analgesic activity of different leaf extracts of Celastrus paniculatus (Willd.) J Adv Pharm Educ Res 2012;2:68-73.

15. Kalam AM, Khanday S, Salim S, Nida K, Ahmad A. Malkangni (Celastrus paniculatus Willd.): Neuropharmacological properties in perspective of unani medicine and pharmacological studies-a review. World J Pharm Pharm Sci 2019;8:381-91.

16. Arif PT, Shaligram SS, Babasaheb KS. Pharmacological profile of jyotishmati (Celastrus paniculatus Willd): A review. Int J Ayush 2018;7:901-23.

17. Malik J, Karan M, Dogra R Ameliorating effect of Celastrus paniculatus standardized extract and its fractions on 3-nitropropionic acid induced neuronal damage in rats: Possible antioxidant mechanism. Pharm Biol 2017;55:980-90.

18. Kokate CK. Practical Pharmacognosy. $4^{\text {th }}$ ed. New Delhi: Vallabh Prakashan; 2005.

19. Patel JV, Galani JV. Investigation of antistress activity of Operculina terpethum roots using various experimental models. Int J Pharmacogn Chin Med 2019;3:1-9.

20. Kanase V, Shaikh S. Evaluation of antistress activity of ethanolic extract of Chromolaena odorata leaves in albino Wistar rats. Asian J Pharm Clin Res 2019;12:50-5.

21. Tiwari N, Mishra A, Bhatt G, Chaudhary A. Anti-stress activity of a bioflavanoid: Quercetin from Euphorbia hirta. Br J Pharm Res 2015;6:68-75

22. Ansari I, Sorte RS. Evaluation of anti-stress activity of ethanolic extracts of Terminalia catappa L. in swiss albino mice. Asian J Pharm Clin Res 2018;11:253-7.

23. Debnath J, Prakash T, Karki R, Kotresha D, Sharma P. An experimental evaluation of anti-stress effects of Terminalia chebula. J Physiol Biomed Sci 2011;24:13-9.

24. Ishola OI, Ashorobi BR, Adeoluwa O. Antistress potential and phytochemical constituents of aqueous root extract of Alchornea cordifolia. Asian J Sci Res 2008;4:476-80.

25. Lotankar RA, Wankhede S, Sharma JB, Momin JA. Anti-stress activity of flavonoids rutin and quercetin isolated from the leaves of Ficus benghalensis. Int J Pharm Pharm Res 2016;5:5-19.

26. Bhanumathy M, Chandrasekar BS, Chandur U, Somasundaram T. Phyto-pharmacology of Celastrus paniculatus: An overview. Int J Pharm Sci Drug Res 2010;2:176-81. 